\title{
EchoGéo
}

$11 \mid 2010$

Madagascar

\section{The use of photo-elicitation in field research}

Exploring Maasai representations and use of natural resources

\section{Elisa Bignante}

\section{(2) OpenEdition}

\section{Journals}

Édition électronique

URL : https://journals.openedition.org/echogeo/11622

DOI : $10.4000 /$ echogeo.11622

ISSN : 1963-1197

Éditeur

Pôle de recherche pour l'organisation et la diffusion de l'information géographique (CNRS UMR 8586)

Référence électronique

Elisa Bignante, "The use of photo-elicitation in field research », EchoGéo [En ligne], 11 | 2010, mis en ligne le 24 février 2010, consulté le 31 juillet 2021. URL : http://journals.openedition.org/echogeo/ 11622 ; DOI : https://doi.org/10.4000/echogeo.11622

Ce document a été généré automatiquement le 31 juillet 2021.

EchoGéo est mis à disposition selon les termes de la licence Creative Commons Attribution - Pas d'Utilisation Commerciale - Pas de Modification 4.0 International (CC BY-NC-ND) 


\section{The use of photo-elicitation in field research}

Exploring Maasai representations and use of natural resources

\section{Elisa Bignante}

\section{NOTE DE L'AUTEUR}

The research activity was possible thanks to the facilities made available by the NGO Oikos and the kind cooperation of Maasai and Meru informants of Mkuru and Iyani subvillages who, for more than a month, participated actively in the research. I'm particularly grateful to Nadia Tecco, who carried out the fieldwork in Tanzania with me and to Jason Lim, who read earlier drafts of the paper and offered critical comments and very helpful suggestions.

When two or more people discuss the meaning of photographs, they try to figure out something together. This is, I believe, an ideal model for research.

Douglas Harper (2002, p. 24) 
Picture 1 - Maasai girls playing with the camera

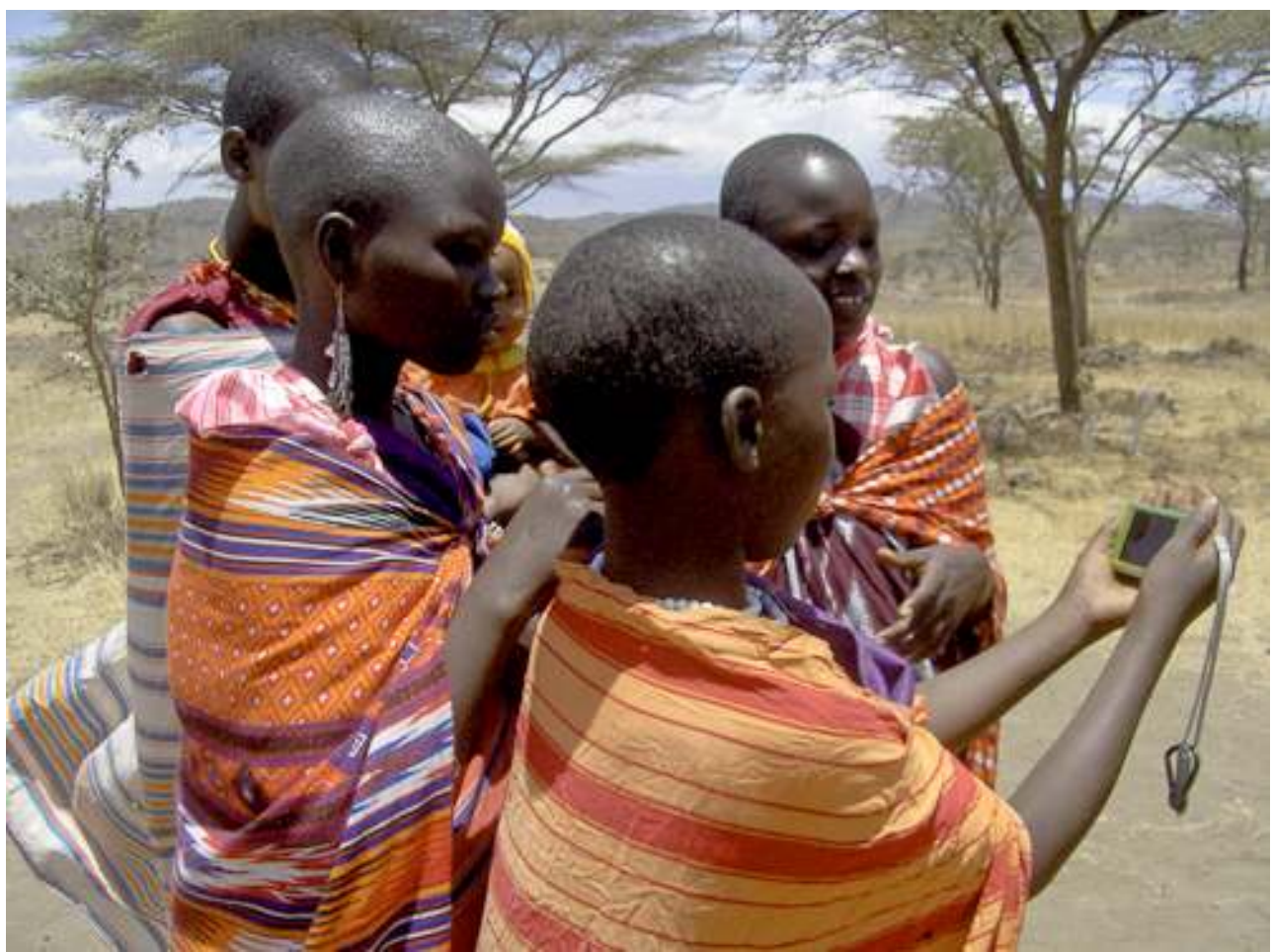

Elisa Bignante, Mkuru, 2008

\section{Photo-elicitation: what it is and how it works}

1 The post modern and culturalist turns that have swept through the social sciences, challenging their objectivity from several points of view, have played a major role in promoting the diffusion of new more "evocative" or non-textual research strategies to capture or explore the values and emotions of social relations more effectively. Photoelicitation $^{1}$, one of the most widely known and frequently used techniques, is based on the fairly simple principle of using one or more images (photos but also videos ${ }^{2}$, paintings or any other type of visual representation) in an interview and asking the informants to comment on them. The images may be produced by the informants (the so-called native image making technique) or may be provided by the researcher. In the first case, covered here, the informants produce the images (with a camera, video camera or other means) and then discuss the meaning with the researcher.

2 A pivotal aspect of this approach is not so much studying the images as analyzing how informants respond to them, attributing social and personal meanings and values (Ruby, 1995). In PEI (Photo-Elicitation Interviewing), the researcher assumes that the images, the meaning(s) we attribute to them, the emotions they arouse in the observer, and the information they elicit generate insights that do not necessarily or exclusively correspond to those obtained in verbal inquiry. Barthes (1981) stresses the polysemic quality of images, i.e. the fact that they have many potential meanings and interpretations. They are therefore uncoded messages to be deciphered according to the person interviewed. Each use and interpretation describes the specific methods through which we observe and experience the world, mediated by social and cultural institutions (Banks, 2001). The activity of observation is, in fact, inextricably linked to 
our way of thinking, imagination, memory of past experiences and our ability to combine these elements.

PEI doesn't aim to replace other forms of enquiry such as traditional interviews. On the contrary, it represents a useful tool both to triangulate between different information sources and potentially to bring different insights into the research.

In the following paragraphs we will examine the role of photo-elicitation in generating insights into informants' cognitive frameworks and their relationships to social and cultural institutions, analysing potential use of photo-elicitation in field research. A recent case study in a Maasai village in northern Tanzania will be presented and discussed.

\section{Using photo-elicitation in Tanzania}

The research project we will be discussing was conducted in northern Tanzania, in the Ngarenyanyuki ward ${ }^{3}$ (Arumeru District) situated at the foot of Mount Meru, to the East of Arusha town and to the North of the Arusha National Park.

Picture 2 - Map of the Arusha National Park and surrounding area

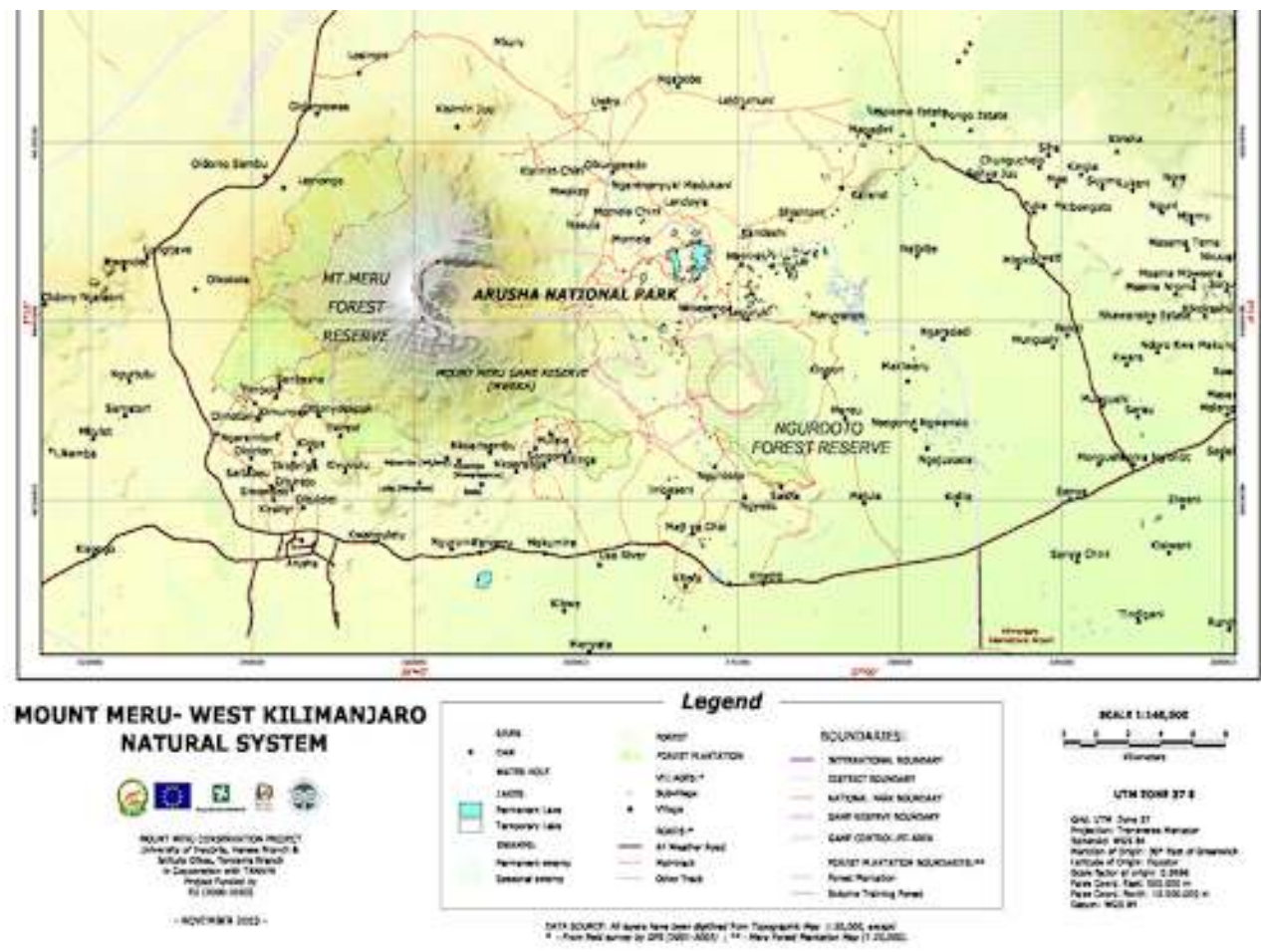

Source : NGO Oikos, 2008

The research done in Tanzania was part of a two-year research project (ParCo protected areas and decentralized cooperation) on the issue of decentralized cooperation, environmental protection and territorial practices, and the aim was to compare different perceptions and representations of nature ${ }^{4}$. The objective of the research project, which included case studies in Tanzania, Senegal and Burkina Faso, was to explore what relationship communities living in and around selected protected 
areas had with the environment, trying to understand the different values and meanings attributed to nature and how these are translated into territorial practices. The research developed different approaches, including participatory mapping with the members of the communities involved in the study, semi structured interviews, transect walking, focus groups and participant observation ${ }^{5}$.

7 In this paper, we will focus more specifically on research done in Mkuru, a sub-village of Uwiro which has 950 Maasai inhabitants. Since nomadic pastoralists started to settle in the ward in the 1980s, the Maasai of Mkuru have become sedentary, with cattle and sheep/goat breeding as their main economic activity. They live in scattered homesteads, generally known as "bomas". Very few Maasai speak Swahili, practically none speak English and they communicate in Maa, the oral language of the Maasai.

Picture 3 -Mkuru - a Maasai booma

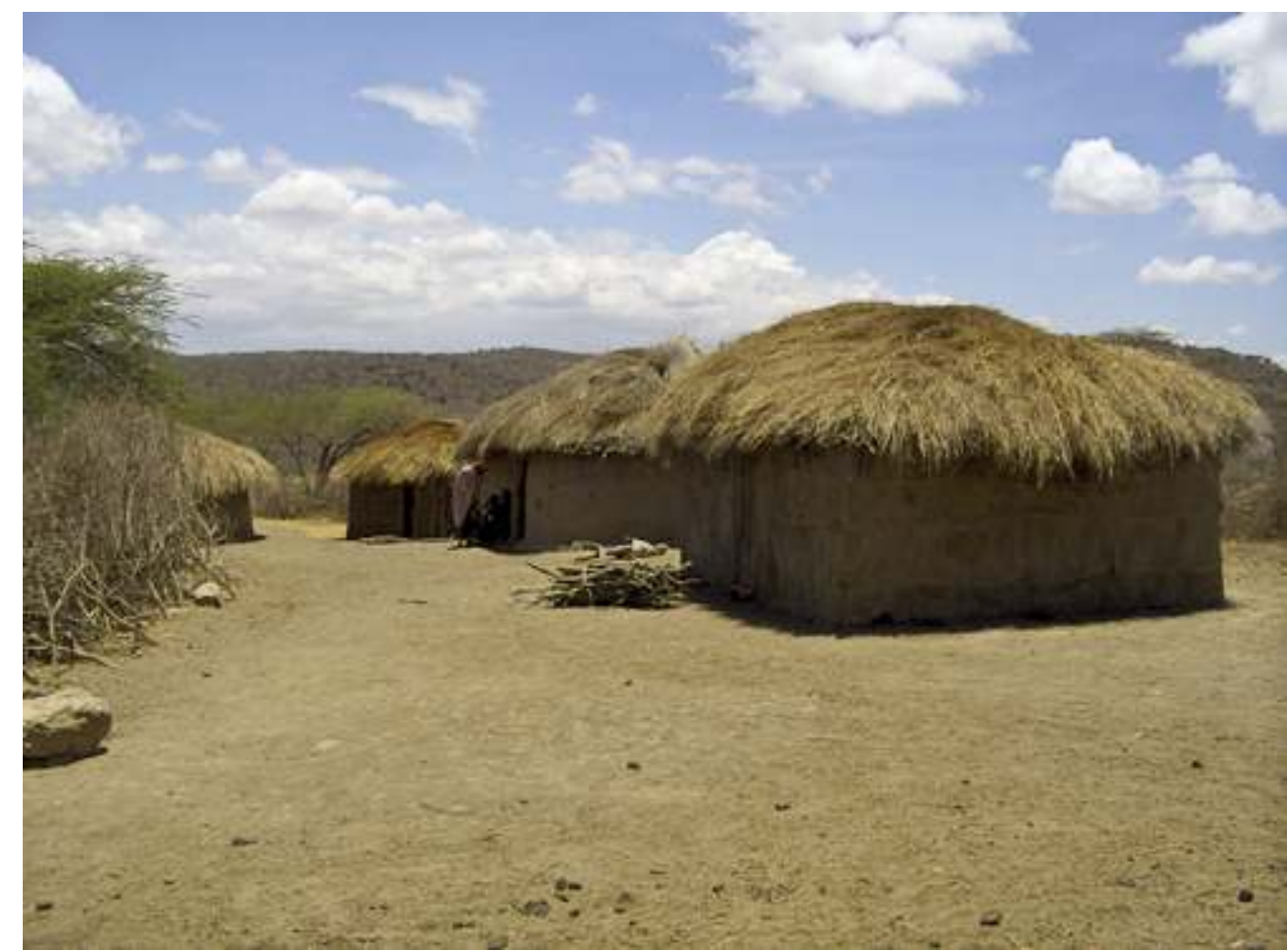

Elisa Bignante, Mkuru, 2008

8 At Mkuru, our aim was to investigate the changes induced by a sedentary lifestyle on the way in which the Maasai use natural resources. We were particularly interested in analysing whether living stably close to other ethnic groups, the need to share subsistence resources with them, the gradual influence of external cultural influences (Christianity, a market economy, international cooperation, etc.) have contributed to modifying the economic, social and cultural relationships between the Maasai and the environment.

9 To analyse these aspects, we used the script of an interview already tested in parallel field research in Burkina Faso and Senegal. The interview, after translation into English and adaptation of certain questions to the local context, was translated into Swahili and Maa. During the interview, questions were asked about the methods for using natural resources in the area, and whether such usage was different in the past. 
Questions were also asked regarding any bans on the use of certain resources, their location and rituals associated with them. In each interview, we were assisted by our interpreter Isaya, chief of the village of Mkuru, who played an important role not only in translating but also in introducing and legitimising our activity with the villagers.

However, in several cases, the interviews - and this situation continued over several days - produced vague replies, silence or embarrassing pauses, clear signs of not only a problem with communication, but also a cultural and relational gap between us and the informants. Situations in which the informants appeared confused, visibly bored or not very interested in the interview alternated with those in which they were eager to provide data and information, in many cases only marginally related to the questions asked.

11 We had, however, noted that the Maasai were very interested in the photographic equipment we used to document the interviews. They were not intimidated by our cameras and must have seen such things in the hands of the tourists who regularly visit their bomas as part of a sustainable tourism project, and they frequently asked to examine and use the camera.

\section{Picture 4 - Playing with the camera and learning how to use it}

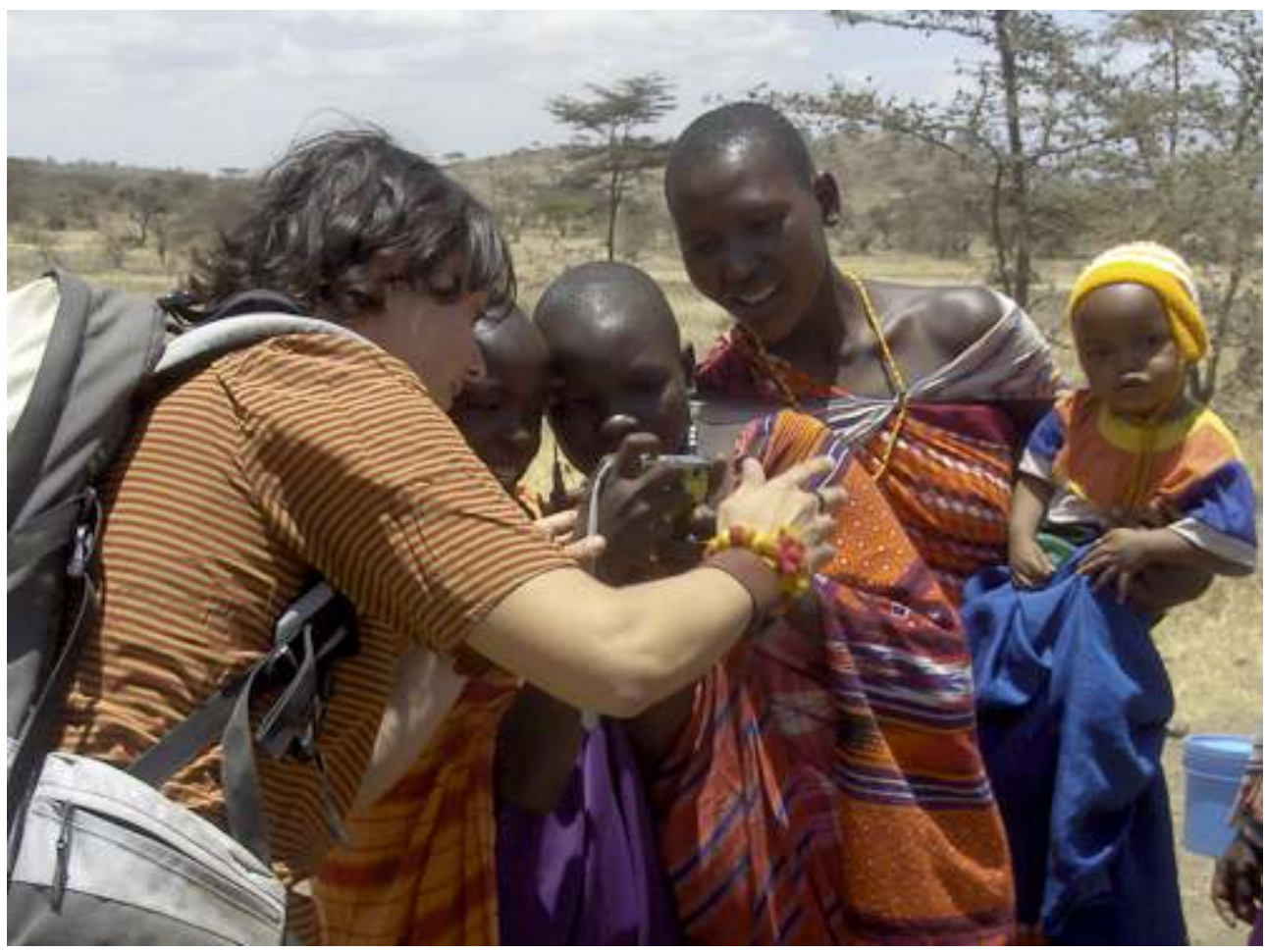

Elisa Bignante, Mkuru, 2008.

We therefore partly reformulated the research activity, continuing to use the script of the interview but inserting two photo-elicitation activities.

In the first activity, the informants were shown photos of "landscapes", with or without anthropic elements, and asked to select the images they preferred. According to the images selected, the pro-environmental behaviour and attitudes of the informants were investigated, adopting the New Ecological Paradigm scale (NEP) (Dunlap and Van 
Liere 1978) - a set of questions focussed on human-environment relations and humans' attitude to natural systems.

Picture 5 - Selecting photographs of environmental landscapes

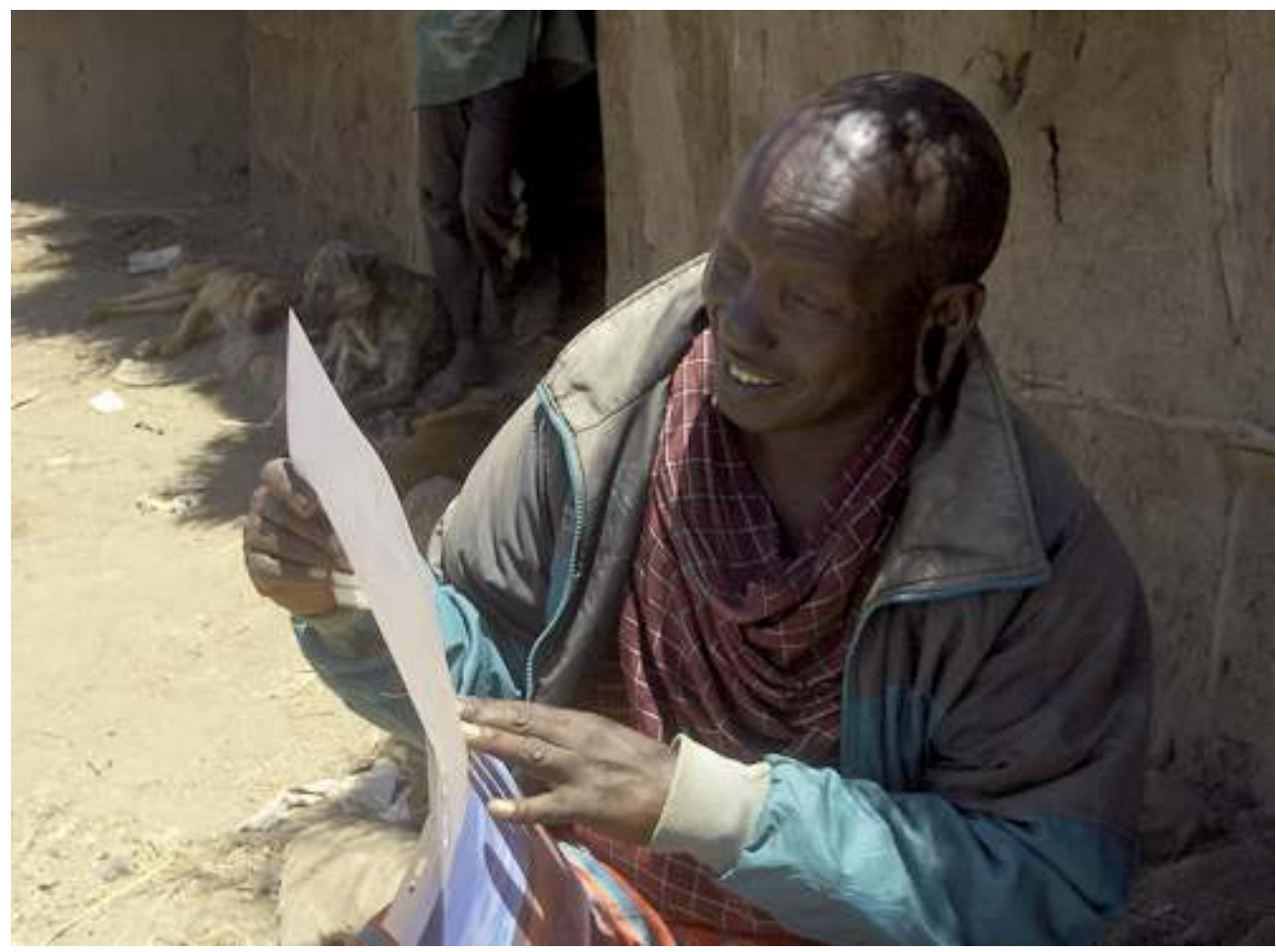

Elisa Bignante, Mkuru, 2008. 
Picture 6 - Selecting photographs of environmental landscapes

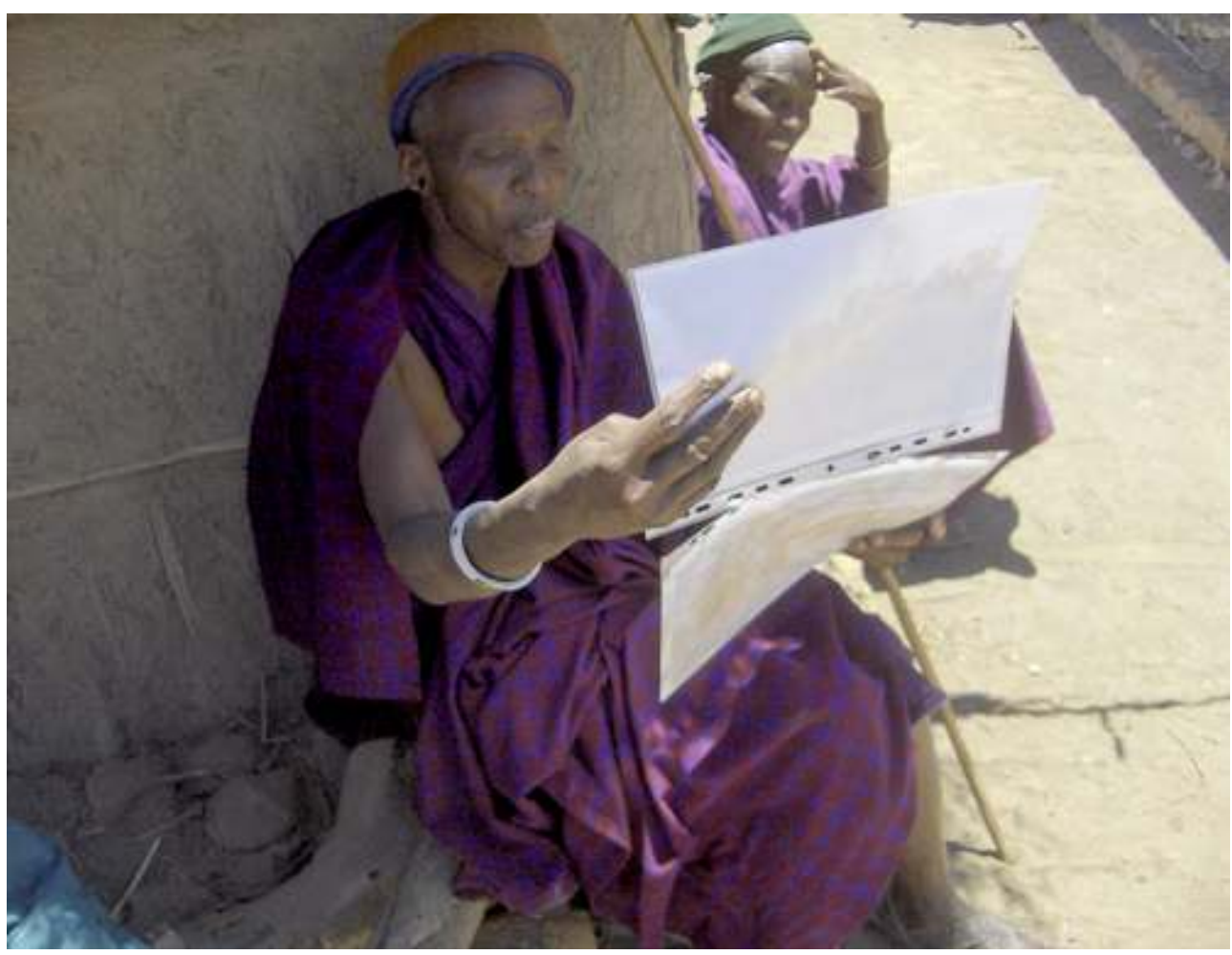

Elisa Bignante, Mkuru, 2008

14 The second activity, which we will focus on here, was a native image making activity. A digital camera was left with a group of volunteer informants; 30 Maasai of different ages and genders ${ }^{7}$ were each asked to take 5 shots to depict the most significant aspects of their land and lives. My colleague and I would follow the informants and mark the site of the picture on a map. An interview would follow in which the informants were asked to give a title to their pictures and to explain the reasons for their choice. 
Picture 7-A young Maasai taking in the photo-elicitation activity

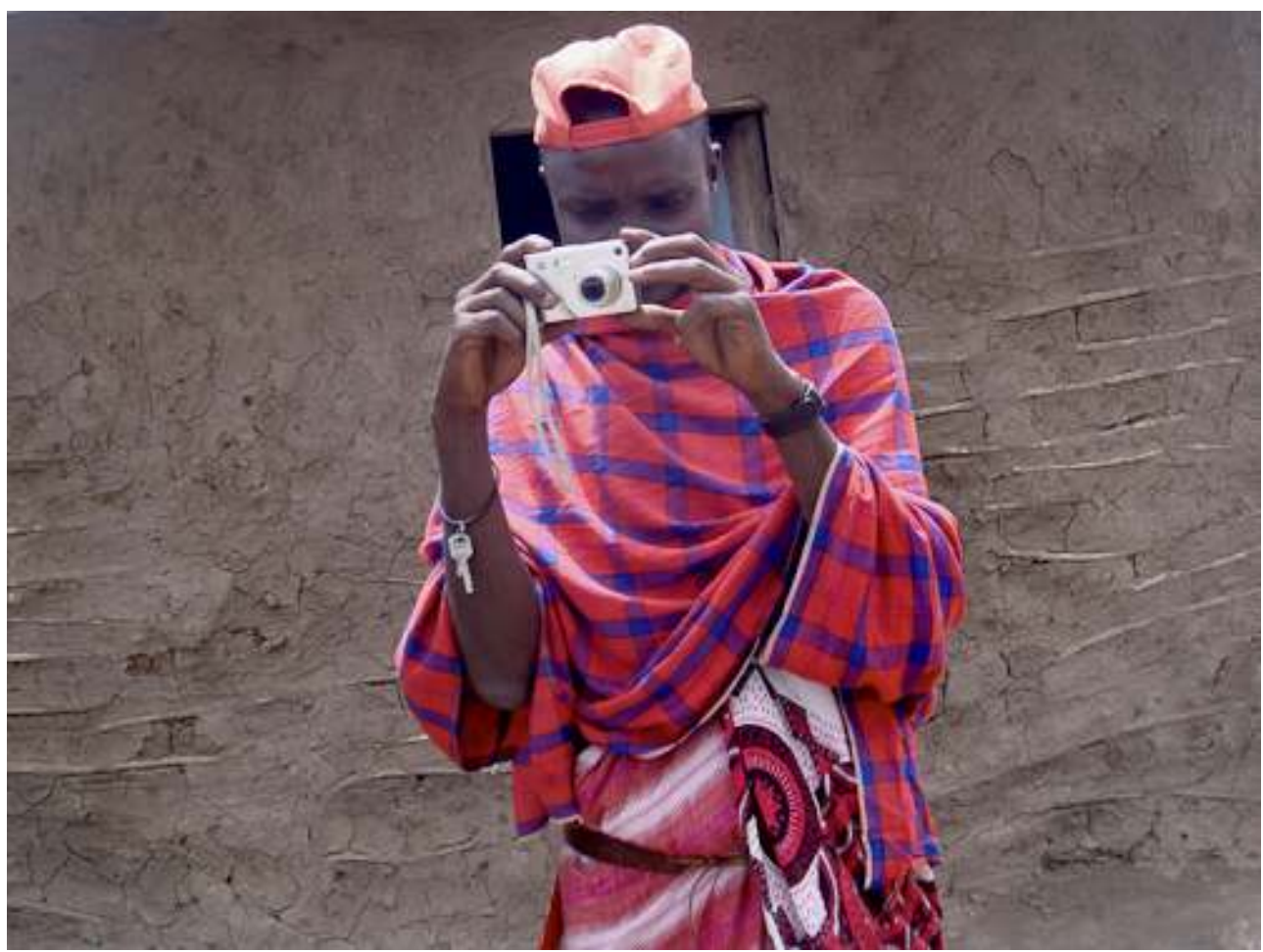

Photographed by Peter, Maasai man, Mkuru, 2008.

\section{Using snapshots to investigate Maasai relationship with the environment}

There are several ways in which a native image making activity can be carried out. It can function as an ice-breaker to let the interviewee enter a particular theme of research, asking him/her to comment on his/her perceptions generally at the end of the activity. The images produced can be used more intensively to ask the informants about their intentions when they took the pictures and the meanings they attribute to each one, in an effort to explore their relationship with the themes of the research in greater depth. Finally, images produced by different informants can be used for more quantitative analysis, for example by comparing what the images show and the frequency with which certain elements in the images recur.

In our study, the images used in the photo-elicitation activities facilitated participants' ability to associate and elaborate meanings. By bringing together their practical knowledge with the researchers' concern with cognitive and social frameworks, photoelicitation enabled a collaborative meaning-making process in which empathy between researchers and informants was established.

Picturing significant aspects of their lives was "easy", something these people felt they were able to do, and it was just as easy for them to comment on their pictures. This also contributed to instilling a clearer more practical perception of the work. The informants also demonstrated greater involvement in the activity than in the first phase based on a conventional interview. On the one hand, they felt they were playing a more active role. On the other, they enjoyed the activity and, as often happens, this 
proved to be much more effective in breaking down relational and communication barriers than sound commitment and even the best intentions. Having enjoyed taking the photos, they then wanted to explain the reason for their choice, to see the images projected on the screen of our laptops, to comment on the pictures and to show them to the curious bystanders who followed the interview.

Reflecting on "what" our Maasai informants decided to photograph, we found that the most frequent elements were (in descending order):

- cows and their pens

- goats, sheep and courtyard animals

- savannah "landscapes"

- plants and bushes

- huts (inside and outside)

- water (springs, buckets and basins for collecting water, dried-up streams, etc.)

- wood

- boma (photos of the inside and outside)

- children

19 The other snapshots show a variety of elements such as tools (calabash for preserving milk, pans, etc.), necklaces produced by the Maasai women and sold to tourists, the local camp of the NGO Oikos, clothes, food, etc.

Picture 8 - Some photos taken by the informants (with the photographer at the Center)

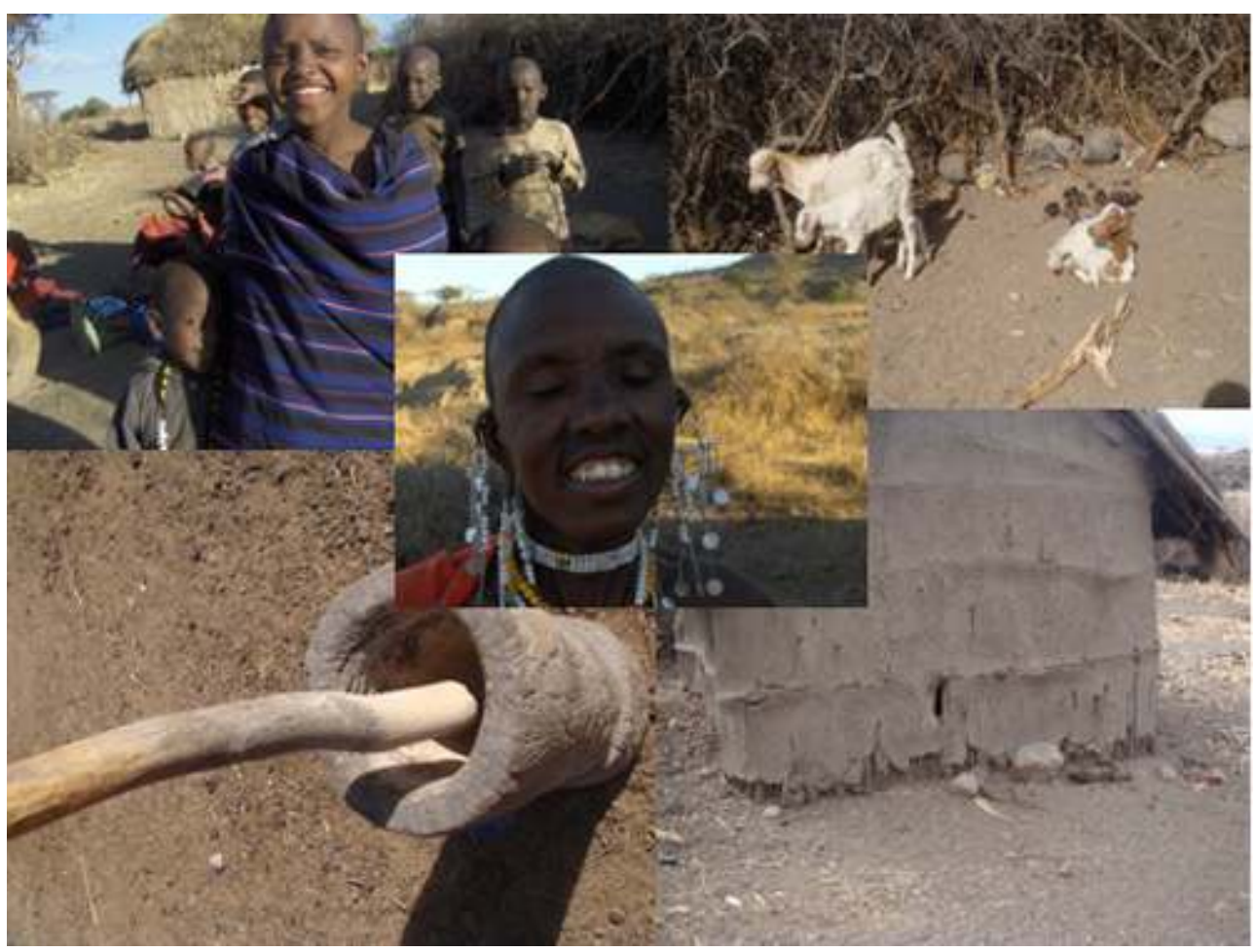

Photographed by Shari, Maasai woman, Mkuru, 2008. 
Picture 9 - Some photos taken by the informants (with the photographer at the Center)

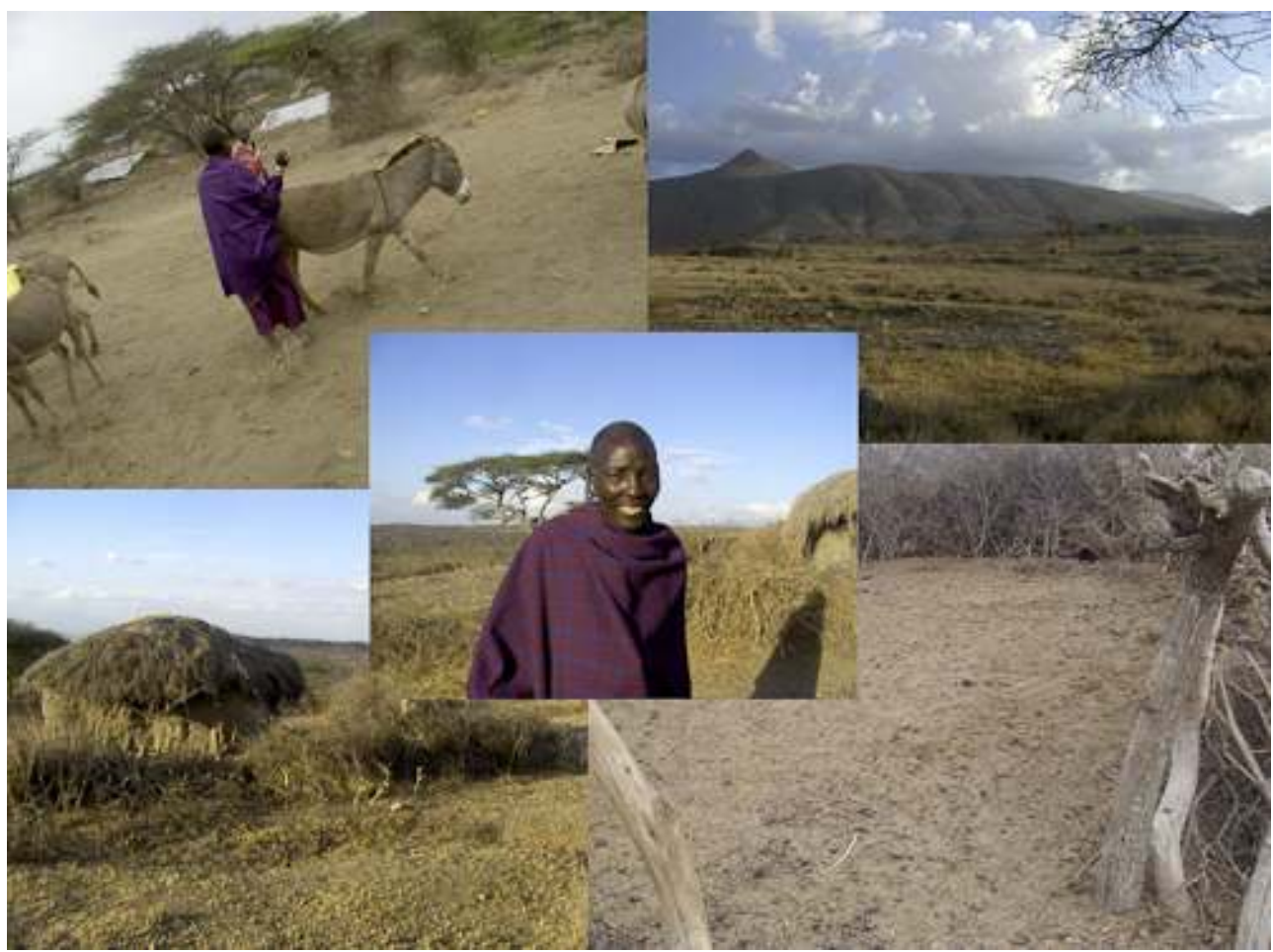

Photographed by Lekunok, Maasai man, Mkuru, 2008.

What information can be obtained from this list? On its own, it lends itself to various interpretations, all of which are merely hypothetical until we ask the authors of the photos for their understandings: for our research, the most important aspect was not so much what was photographed but rather the reasons for selecting that particular content and the relationship between this selection and the topic investigated. Although content analysis showing how frequently the same subject appears in the images can provide significant information regarding the presence or absence of certain elements and the way in which these elements are photographed (for example, whether differences exist between photos of the same subject and, if so, what these differences are), what clearly emerges is that the images photographed led to more questions rather than providing replies. For example, why have cows and pens been photographed? What meaning can be assigned to the views that (for the moment and in a rather ethnocentric manner) we have dubbed savannah "landscapes"? Moreover, when analysing the images, there is a risk that the researcher may, in some cases, contaminate these with his/her personal understandings and interpretations regardless of the understandings and intentions of those who took the photographs.

21 Examining the titles given by each informant to his/her snapshots provides a starting point for understanding the meanings the informants associated with their images. For example, the above-mentioned savannah landscapes had different meanings for different informants: some wanted to show the fields where they take the animals to graze; others a particular path; and others specific places such as the sacred mountain Oldoinyo Lengai, the mountain of God, or the baboon cave where the ceremonies for transfer of knowledge known as Orpul are held. 
Picture 10 - The baboon cave

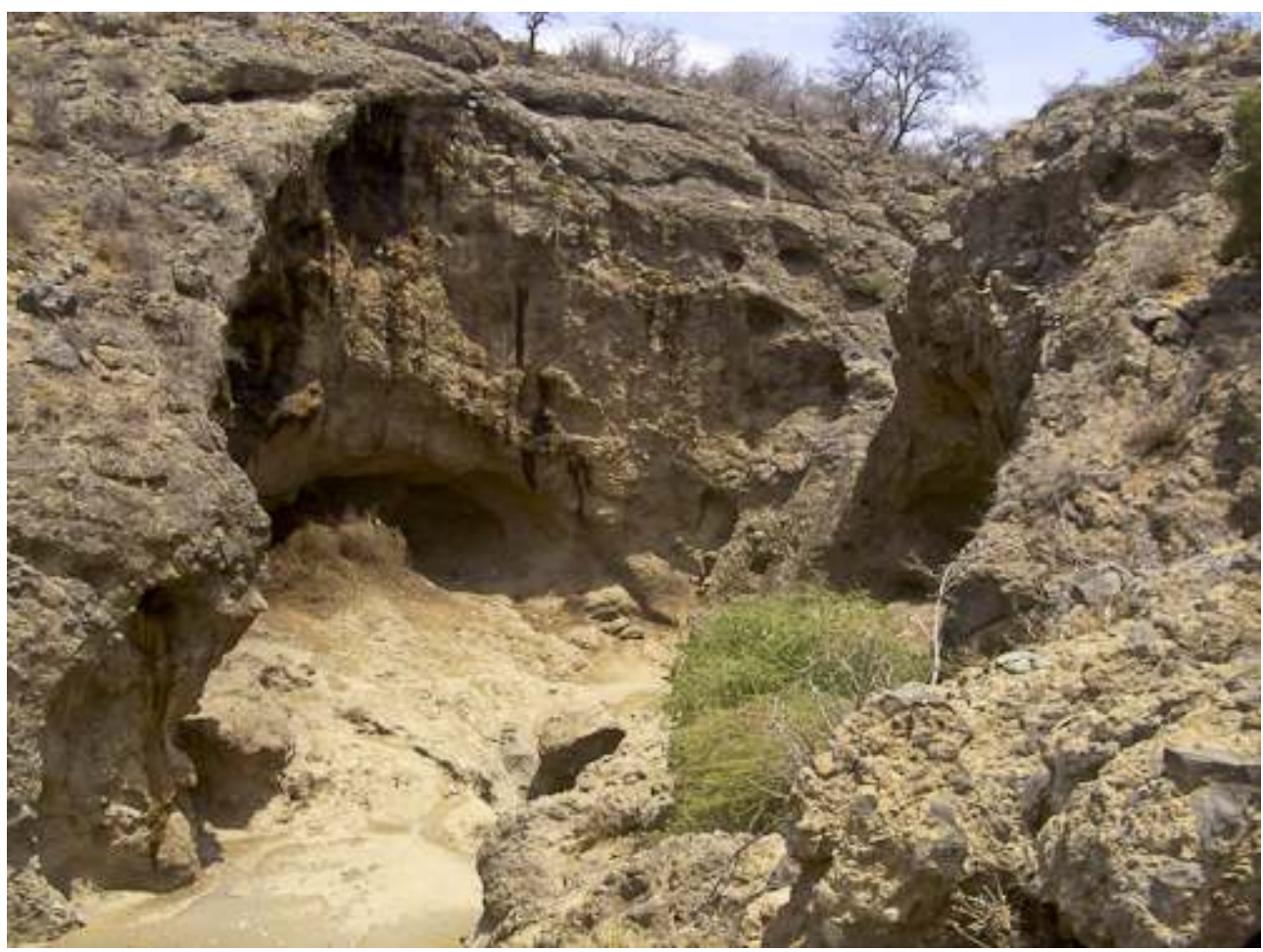

Elisa Bignante, Mkuru, 2008

\section{Picture 11 - Grazing land}

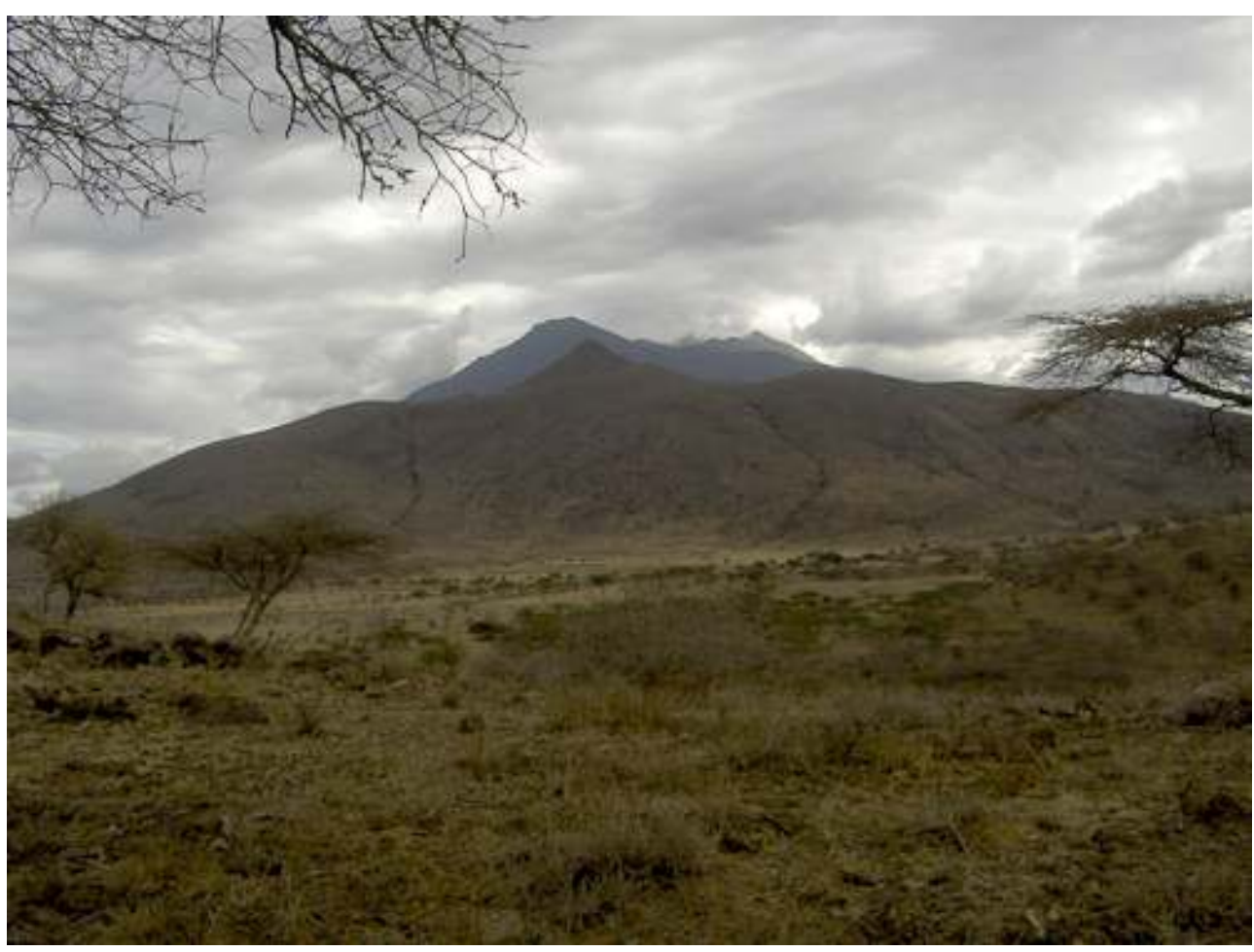

Photographed by Gabriel, Maasai man, Mkuru, 2008 
Similarly, the interpretations of images which appear more obvious to the researcher it is not difficult, for example, to presume that animals will be selected as one of the most important elements of the habitat in a pastoral society where wealth, social prestige, the favour of ancestors, happiness and personal achievement are measured according to the number or condition of cattle owned - may conceal more complex meanings, which could encourage exploration of transversal territorial practices. Often, the images that we decided to sift through quickly because they seemed "less interesting" later turned out to reveal important information about Maasai territorial practices and relationships with nature. When commenting on photos of "livestock pens", the various informants drew attention to a number of more specific issues, which differed case by case: the death of cows; the use of plants and bushes to cure ill cows; methods for recognising the most fertile pastures, the practices adopted to acquire and transmit this knowledge, and the places where this knowledge is transferred. For example, when commenting on the photo of a pen, one of the informants felt it was important to describe how it was built, going on to describe the problems involved in finding wood and new methods to overcome increasing its scarcity.

More generally, compared with the conventional interviews held in the early stages of the research, we noted that PEI produced replies more closely linked to the informant's immediate social and emotional sphere ("I wish I had more cows so I could marry that woman", "I enjoy making necklaces for tourists because I can spend the money I earn on myself and my children", etc.).

Picture 12 - Pens

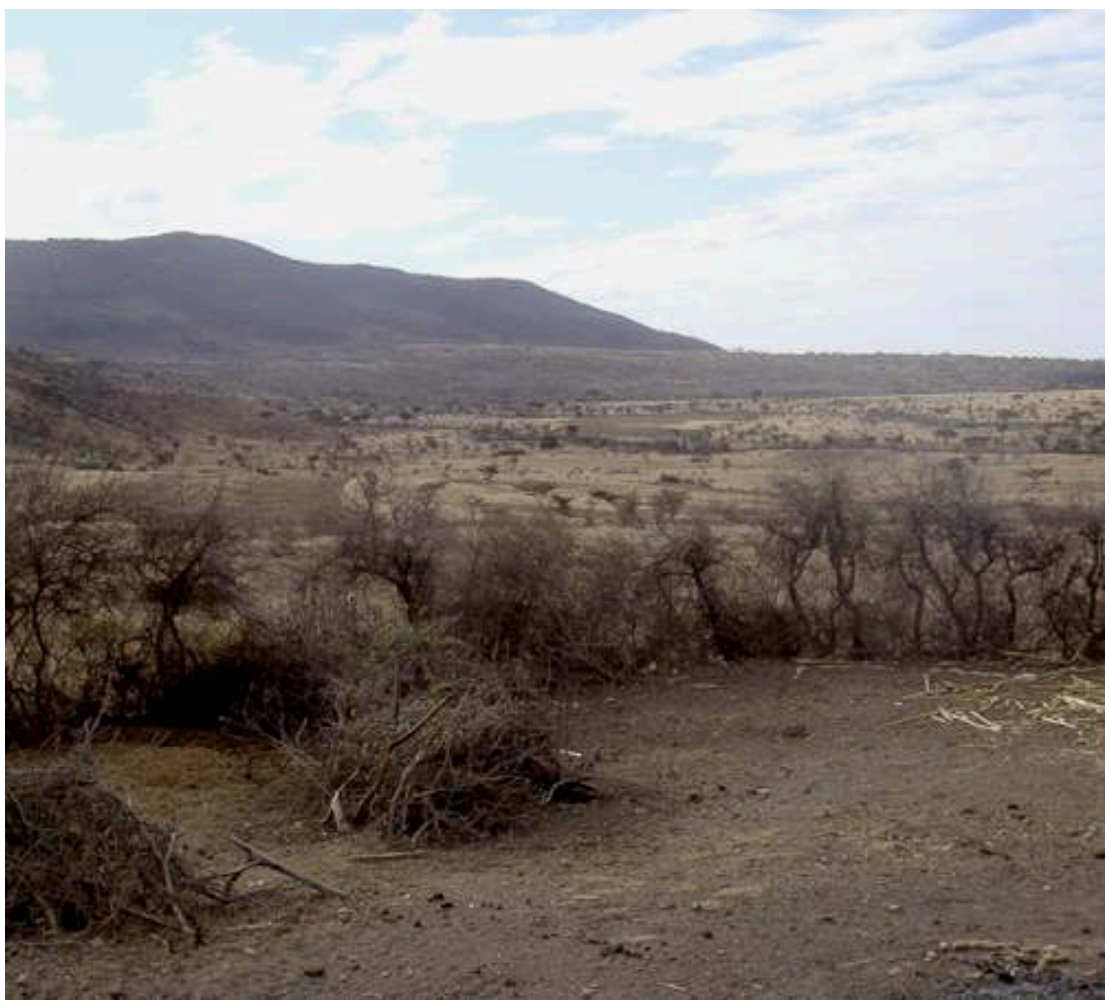

Photographed by Grace, Maasai woman, Mkuru, 2008 
The above discussion leads us to emphasize, once again, that the snapshot must be considered not a point of arrival but of departure in exploring informants' understandings and perceptions. However, in this process, there is an inherent risk that the researcher, following the informants' "stream of consciousness", may be enticed to venture along other paths, moving away from the rationale of the study. The researcher's must constantly strive to strike the right balance between the desire to let informants express themselves freely, being open to unexpectedly interesting insights that arise during the course of the research, and rigour in ensuring research objectives are addressed and discussion is re-directed to the subject of inquiry. However, it is not easy to know when digression might be useful in achieving research goals (or result in improved empathy between researcher and informant) or is simply misleading.

Picture 13 -Discussing the meaning of photographs with some Mkuru Maasai women

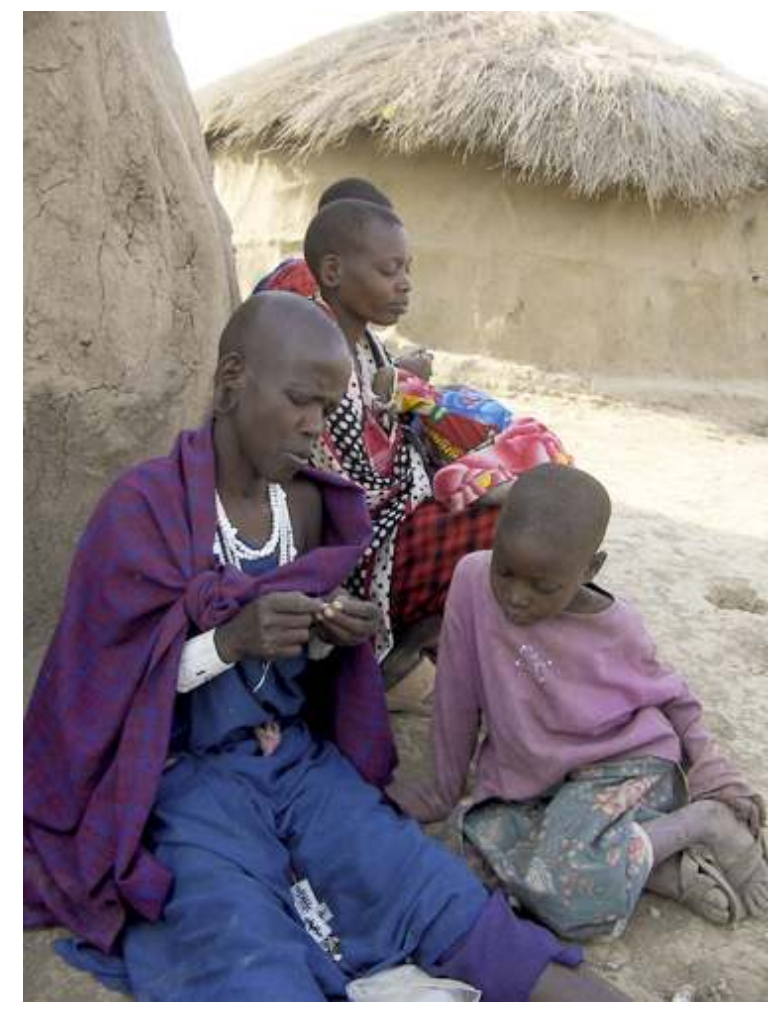

Elisa Bignante, Mkuru, 2008

A great deal depends on how the photo-elicitation technique is understood and used. For example, in some research projects, PEI is used to break the ice, to create a comfortable space for discussion and good rapport between researchers and informants, all in order to hold a conventional interview. In other cases, photoelicitation is used in a preliminary phase to gather data to be used subsequently to define the object of the research more clearly and to adapt the interviews accordingly. In these cases, a "digression" may make it possible to collect potentially important information. In yet other cases, photo-elicitation represents the core activity of the research, and the interviews revolve entirely around the images. Our research used PEI in several ways. As already mentioned, the production of images was initially useful as it created a bond between interviewee and interviewer. Moreover, informants had not yet had the expectations of their role in the research explained to them so PEI 
facilitated the communication of these expectations and the overall aims of the research. Subsequently, we realized that, by asking informants to comment on the images, we were able to build an in-depth knowledge of certain territorial dynamics, which then proved useful for initiating a subsequent phase of more aware, targeted investigation.

Picture 14 - A moment of discussion

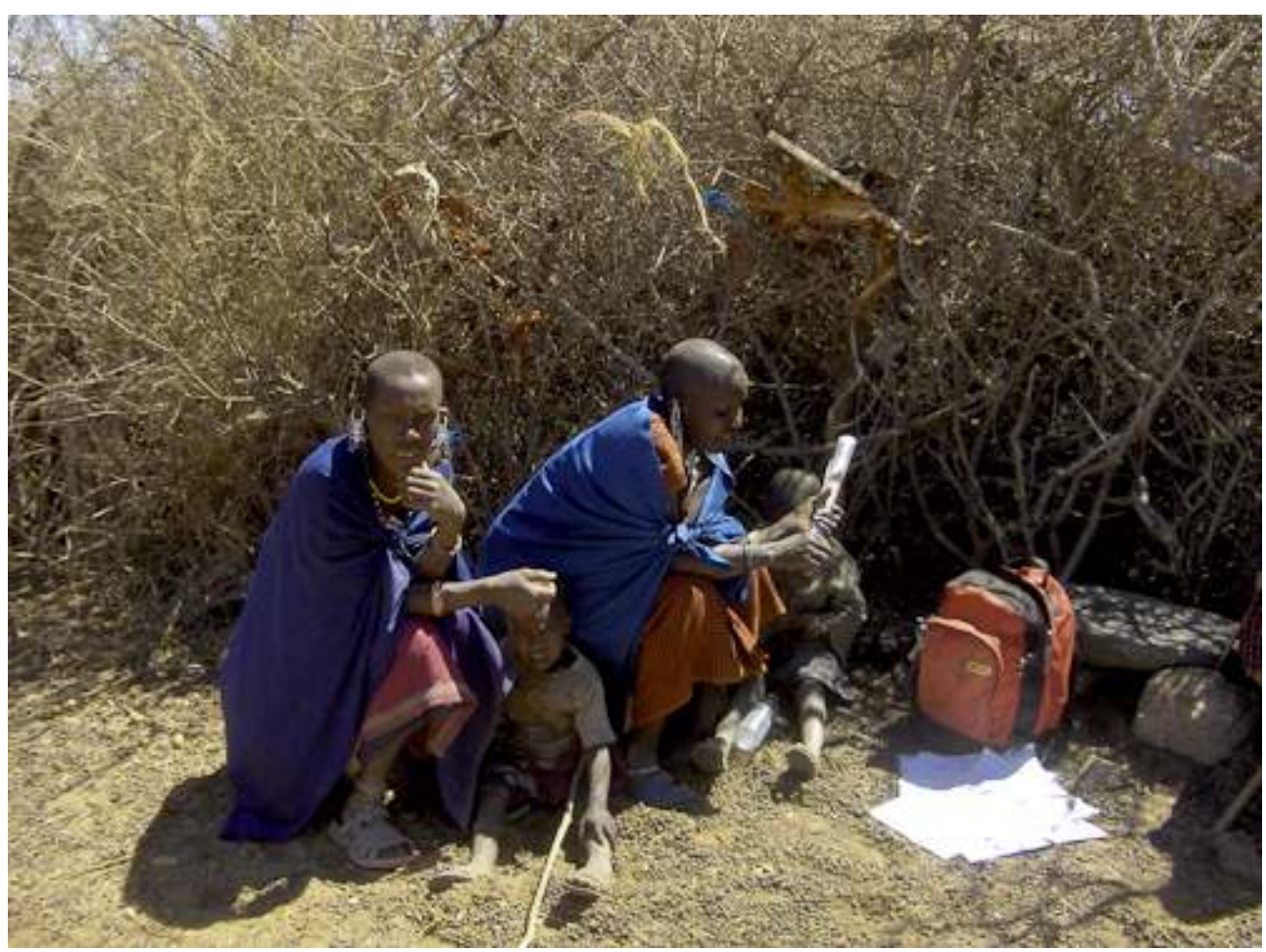

Elisa Bignante, Mkuru, 2008

Therefore, with questions intended to prompt, probe and interrogate informants' comments, topics were covered such as how environmental conservation techniques are learnt and how changes have occurred in the use of specific natural resources such as wood, water and medicinal plants.

We were able to study the role of the Maasai - the protagonists of many studies on biodiversity conservation (see inter alia Conant, 1982, Collet, 1987; Swift, 1988; Western, 1989, 1997; Ellis and Swift, 1998) - in the broader environmental changes taking place in the region.

In some ways, the Maasai are key players in the environmental conservation of the Mkuru area, with rules and norms of behaviour that influence their relationship with nature. On these matters, visual enquiry made it possible to appreciate various capabilities the Maasai have for environmental regulation: pastoral practices and their contribution to maintaining a productive habitat for wildlife (as suggested also by Western, 1989); knowledge in terms of monitoring the spatial displacement of wildlife (see also Goldman, 2007); knowledge about the location of water sources; and knowledge about the use of medicinal plants (see also Ibrahim and Ibrahim, 1998).

29 On the other hand, PEI underlined some major changes in the Maasai's relationship with the environment. In particular, it showed how the creation of the Arusha National 
Park $^{8}$ in colonial times (Neumann, 1998) has contributed to less attention and action aimed at the protection of certain natural resources. The creation of the national park has progressively led to greater pressure on the land and increased interaction and conflict among neighbouring ethnic groups. Moreover for the Mkuru Maasai, increased sedentarization means that it is more difficult to move to other areas to look for wood when it starts to become scarce in the area, as they did in the past, and in time they have adapted the technique used by their neighbours the Meru who produce coal by burning wood in the savannah' ${ }^{9}$. Likewise, wildlife that was for years protected by the Maasai (Goldman, 2003) (who unlike other neighbouring groups such as the Meru are not active hunters) is now seen as being outside of the Maasai's sphere of influence (and protection). When commenting on the pictures taken, some Maasai, as has been shown in other studies (Goldman, 2007), referred to the wildlife as "animals of the State" or "Park animals". Some admitted hunting and eating wild animals, when possible, in other words when the park rangers aren't looking.

From a methodological point of view, exploring such themes through PEI helped establish questions to be investigated in further depth in subsequent inquiries based on conventional interviews. For example, the research highlighted that the practice of gathering and transforming plants for therapeutic purposes was very common in Mkuru, but this aspect only came about through triangulating and further investigating data arising from informants' comments about certain images (of animals, bushes, children etc.). During territorial transects, the informants were able to list, identify and describe the use of around one hundred medicinal plants.

Picture 15 - Osukuroi, medicinal plant

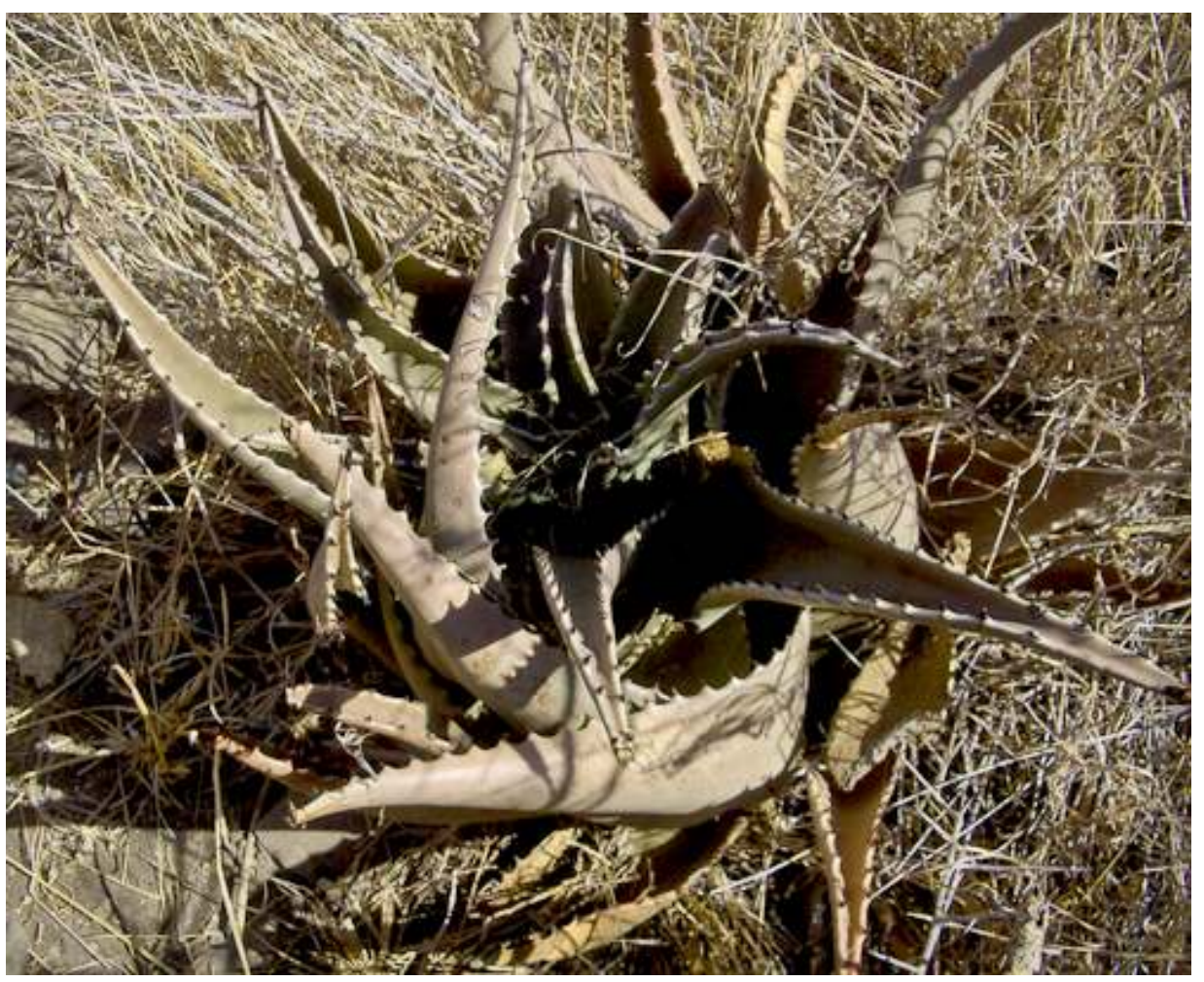

Elisa Bignante, Mkuru, 2008 
Some of the informants photographed specific plants, describing their healing properties and how they are collected and transformed; others, referring to views of the savannah, reeled off long lists of all known phytotherapeutic remedies and their distribution in the territory, the diffusion of this knowledge and the sale of the natural remedies produced. In particular, we were able to verify how the spread of Christianity gradually modified this knowledge, imbuing it with different meanings, and how other neighbouring ethnic groups' loss of knowledge regarding the transformation of these plants has made the Maasai key players in the territory, safeguarding this cognitive background. As these issues were important with regard to the research goals, conventional interviews were subsequently held with the whole group (200 Maasai) in order to collect further data on the transformation, use and sale of medicinal plants. This theme is emphasized in order to highlight how photo-elicitation can be positively integrated with conventional interviews that, based on a set of specific, clearly-defined questions, can investigate specific issues on a larger sample in a reasonably short time. From this point of view, the two methods are not mutually exclusive but can effectively complement one another. The informant-driven production activity was also combined with other methods of inquiry: transects; maps drawn by the informants that, for example, identified and located natural resources; focus groups; and participant observation. This made it possible to improve the quantity and type of data collected and to enlarge the sample, interviewing a higher number of informants than would have been possible if only using the more time-consuming technique of photoelicitation.

\section{On the matter of when and how to use photo- elicitation}

Finally, with reference to our Tanzanian experience, I would like to comment more broadly on the role of photo-elicitation in field research.

Firstly, our research shows that photo-elicitation doesn't replace studies based on conventional interviews and can be viewed as an adjunct to such methods, providing additional validity and depth, and offering new viewpoints and opportunities. Clearly, this technique does not always work, and its use is not always appropriate (or rewarding). As photo-elicitation is a relatively time-consuming activity (for researchers and informants), it should preferably be adopted when it can provide an effective contribution to the research. Secondly, photo-elicitation stimulates the informants' ability to express their practical knowledge through the attribution and association of meanings. In these activities, the informants will not only provide information, but they will also be asked to describe their perceptions of specific phenomena and the values they attribute to them. Depending on the rationale of the research, this type of information may be relevant or, on the contrary, represent only time-consuming digressions. It must also be considered whether, in certain contexts, this technique will be rejected or not readily accepted by the informants. The interest in photographic equipment shown by the Maasai in Mkuru was decisive for the research project's success. On the other hand, attempts to use photo-elicitation techniques in neighbouring villages of the Kaborè Tambi park in Burkina Faso as part of the same research project ( $\mathrm{ParCo}$ ) failed (and have been abandoned) mainly because the informants felt uncomfortable using the camera. 
are many things to consider when deciding on whether or not to use photoelicitation in a research project, but as our research and that of others (including inter alia El Guindi, 1998; Blinn and Harrist, 1991; Bolton et al., 2001; Dodman, 2003) has shown, photo-elicitation can be a useful technique for breaching the communication impasse between interviewee and interviewer, for bridging geographical and cultural gaps between interviewee and interviewer, and for collecting more quantitatively and qualitatively complete data compared to that obtained by using "words" only. Photoelicitation can help to promote more relaxed and more aware participation in the research, firstly, by exploiting the evocative power of images to empower informants to express themselves more freely in producing the snapshots and, secondly, by exploiting the power of images to catalyse informants' exploration and association of meanings and understandings in the discussions about the snapshots. This is what happened in Mkuru, in particular when we were able to establish an effective link between the content of the images produced, the informants' understandings and the topic of the research. Photo-elicitation also proved useful in challenging certain mindsets that lead researchers (often unconsciously) to seek specific pre-conceived replies from informants; instead, photo-elicitation allowed the construction of new frameworks of understanding with the informant, creating a bridge between the different "experiences of reality" both parties bring to the research (Pink 2007).

If there is the time, will and opportunity to adopt photo-elicitation - and when it is compatible with the research goals - the most interesting possibility offered by its use would seem to be the establishment of a dialogue in which complementary and concurrent understandings of the physical, social and cultural milieu of the actors can be built and explored.

\section{BIBLIOGRAPHIE}

Arhem K., 1985. Pastoral Man in the Garden of Eden: The Maasai of the Ngorongoro Conservation Area, Tanzania, Uppsala Research Reports in Cultural Anthropology, Uppsala, University of Uppsala.

Banks M., 2001. Visual Methods in Social Research. London, Sage.

Barthes R.,1981. Camera Lucida. New York, Hill and Wang.

Blinn L., Harrist A.W., 1991. Combining native instant photography and photo-elicitation. Visual anthropology, 4, p. 175-92.

Bolton A., Pole C., Mizen P., 2001. Picture this: Researching child workers. Sociology, 35, p. 501-18.

Brockington D., Homewood K., 1999. Pastoralism around Mkomazi Game Reserve: The interaction of conservation and development. In M. Coe, N. McWilliam, G. Stone, M. Packer (eds.), Mkomazi: The Ecology, Biodiversity, and Conservation of a TanzanianSavannah, London, Royal Geographical Society (with the Institute of British Geographers), p. 513-530.

Collet D., 1987. Pastoralists and wildlife: Image and reality in Kenya Maasailand. In D. Anderson, R. Grove (eds.), Conservation in Africa, Cambridge, Cambridge University Press, p. 129-48.

EchoGéo, 11 | 2010 
Collier J., 1957. Photography in anthropology: a report on two experiments. American Anthropologist, 59, p. 843-859.

Collier J., Collier M., 1986. Visual Anthropology: Photography as a Research Method (revisedand expanded). Albuquerque, University of NewMexico Press.

Conant F. P., 1982. Thorns paired, sharply recurved cultural controls and rangeland quality in East Africa. In Spooner B., Mann H. S. (eds.), Desertification and Development: Dryland Ecology in Social Perspective,Academic Press, London, p. 111-122.

Connor L., Patsy A., Timothy A., 1986. Jero Tapakan: Balinese Healer, an Ethnographic Film Monograph. Cambridge, Cambridge University Press.

Cowan P., 1999. 'Drawn' into the community: Reconsidering the artwork of Latino adolescents. VisualSociology,14(1/2), p. 91-107.

Dodman D.R., 2003. Shooting in the city: an autophotographic exploration of the urban environment in Kingston, Jamaica. Area, 35, p. 293-304.

Dunlap R.E., Van Liere K.D., 1978. The 'new environmental paradigm': A proposed measuring instrument and preliminary results. Journal of Environmental Education, 9, p. 10-19.

El Guindi F., 1998. From pictorializing to visual anthropology. In H. R. Hernard, (ed.), Handbookof Methods in Cultural Anthropology, London, Sage, p. 459-511.

Ellis J. E., Swift D.M., 1998. Stability of African pastoral ecosystems: Alternate paradigms and implications for development.Journal of Range Management, vol. 41, 6, p. 450-459.

Goldman M., 2003. Partitioned nature, privileged knowledge: Community-based conservation in Tanzania. Development and Change, 34, 5, p. 833-862.

Goldman M., 2007. Tracking wildebeest, locating knowledge: Maasai and conservation biology understandings of wildebeest behaviour in northern Tanzania. Environment and Planning D: Society and Space, 25, p. 307-331.

Harper D., 1984. Meaning and work: a study in photo-elicitation. International Journal of Visual Photography, 2, p. 20-43.

Harper D., 1993. On the authority of the image. In N.K. Denzin and Y.S. Lincoln (eds.), Handbook of Qualitative Research, Thousands Oaks, Sage, p. 403-414.

Harper D., 2002. Talking about pictures: A case for photo elicitation. Visual Studies, vol. 17, 1, p. 13-26.

Homewood K., Rodgers W., 1991. Maasailand Ecology: Pastoralist Development and Wildlife Conservation in Ngorongoro, Tanzania. New York e Cambridge, Cambridge University Press. Ibrahim F., Ibrahim B., 1998. The Maasai herbalists in Arusha town, Tanzania.GeoJournal,46, p. 141-154.

Knowles C., Sweetman P., (eds.),2004. Picturing the Social Landscape: Visual Methods and the Sociological Imagination. London, Routledge.

Neumann R. P., 1998. Imposing Wilderness: Struggles over Livelihood and Nature Preservation in Africa. University of California Press, Berkeley.

Pink S., 2007. Doing Visual Ethnography: Images, Media and Representation in Research. London, Sage (first edition 2001). 
Prosser, Jon, (ed.), 1998. Image-based research: A Sourcebook for Qualitative Researcher. Bristol, PA, Falmer Press.

Rose G., 2007. Visual Methodologies: an Introduction to the Interpretation of Visual Materials. London, Sage (first edition 2001).

Ruby J., 1995. Secure the Shadow; Death and Photography in America. Cambridge, MA, MIT Press.

Wagner J., (ed.), 1979. Images of Information. Sage publications, Beverly Hills/London.

Western D., 1997. In the Dust of Kilimanjaro. Island Press, Washington DC.

Western, D., 1989; Conservation without parks: Wildlife in the rural landscape. In D. Western, M. Pearl (eds.), Conservation for the Twenty-first Century, New York, Oxford University Press, p. 158-67.

\section{NOTES}

1. The term photo-elicitation was first adopted by photographer and researcher John Collier (1957) who, in a multi-disciplinary research project on housing, proposed using photographs in interviews in order to examine how certain immigrant families adapted to living amongst ethnically different people. For more detailed information on the theoretical-methodological aspects of photo-elicitation, see Collier and Collier (1986), Wagner (1979), and Harper (1984, 1993, 2002). For a more complete introduction to visual research methods, see Prosser (1998), Banks (2001), Knowles and Sweetman (2004), Pink (2007), Rose (2007).

2. As, for example, in the works of Connor et al. (1986) and Cowan (1999).

3. More than $90 \%$ of Ward inhabitants are Meru people; other ethnic groups include the Waarusha, Chagga and the Maasai with different distributions in the five villages of Ngabobo, Olkung'wado, Kisimiri Chini, Kisimiri Juu and Uwiro.

4. The research, financed by Fondazione CRT (Progetto Alfieri) and Regione Piemonte, was conducted by a research team of the Polytechnic and University of Torino, coordinated by Prof. Egidio Dansero. It involved various partners including NGOs, Italian and African protected areas authorities and Italian, Senegalese, Tanzanian and Burkinabè researchers.

5. In Tanzania, 380 interviews were conducted with members who belonged to two ethnic groups - Meru (180 interviews) and Maasai (200 interviews) - and who were of different age and gender (including 70 Maasai and 40 Meru children). Eleven focus groups were organised among women, young people and adults of the two communities. Participant observation and participatory mapping were also carried out in different communities living in the Ngarenyanyuki ward. Some of the people interviewed were willing to take transect walks in the surrounding savannah, allowing plant collection and identification and allowing detailed information to be gathered on methods used for grazing, cultivation, wood gathering, locating water sources, etc.

6. Each boma comprises an enlarged family and consists of several huts protected by a common shield of live fence or dried acacia branches.

7. The sample was composed as follows: 5 elders ( 3 men and 2 women), 14 adults ( 8 men and 6 women), 3 young men and 5 young women (between 15 and 25 years of age), 3 children ( 2 boys and 1 girl).

8. In general, as has been documented, the creation in colonial times of national parks in Kenya and Tanzania, often implemented with coercive measures, meant a loss of land and pastures (and to a lesser extent land used to grow crops), limited access to resources essential for survival such as wood and water, alienation from homelands, conflict and hardship in protected areas (see Arhem, 1985; Homewood and Rogers, 1991; Brockington and Homewood, 1999). 
9. The intervention of the Arusha National Park Rangers and the NGO Oikos has limited this practice in recent years.

\section{RÉSUMÉS}

This paper examines the use of visual methods in geographical field research, and in particular photo-elicitation. The technique involves photos, videos and other forms of visual representation used in an interview, with informants asked to comment on the images. The aim is to promote more direct involvement of the informants in the research process and to encourage and stimulate the collection of quantitatively and qualitatively different information to that obtained in conventional interviews.

The potential and limitations of this technique in the field are investigated, describing and discussing photo-elicitation data collection in the Maasai village of Mkuru in northern Tanzania to explore the use and preservation of natural resources. Results and methodological insights from the fieldwork are presented and discussed.

\section{INDEX}

Keywords : Maasai, native image making, natural resources, photo-elicitation, photographs.

\section{AUTEUR}

\section{ELISA BIGNANTE}

elisa.bignante@unito.it 